\title{
IbM KELOMPOK BISNIS PETERNAKAN KAMBING DAN DOMBA SEBAGAI HEWAN QURBAN DAN AQIQOHAN DI KARANGBESUKI, SUKUN, MALANG
}

\author{
Usman Ali ${ }^{1}$, Sumartono ${ }^{2}$ dan Nurul Humaidah ${ }^{3}$ \\ ${ }^{1}$ Fakultas Peternakan Universitas Islam Malang \\ email: usmanchalim@gmail.com \\ ${ }^{2}$ Fakultas Peternakan Universitas Islam Malang \\ email: sumartono_56@yahoo.com \\ ${ }^{3}$ Fakultas Peternakan Universitas Islam Malang \\ email: nurul_humaidah@unisma.ac.id
}

\begin{abstract}
ABSTRAK
Bisnis peternakan kambing dan domba sebagai hewan qurban dan aqiqohan secara intensif dapat mendatangkan pendapatan dan keuntungan besar bagi peternak.Tujuan program Ipteks bagi masyarakat (IbM) ini untuk meningkatkan pengetahuan dan ketrampilan peternak dalam berbagai bidang agrobisnis yaitu pemeliharaan kambing - domba, strategi pengadaan dan pemberian pakan berkualitas, penghijauan lahan sistem tiga strata, manajemen produksi dan sistem pemasaranyang tepat. Program IbM ini menggunakan beberapa metode yang dilakukan secara bertahap yaitusosialisasi dan perijinan, penyuluhan, demo plot, pembinaan dan konsultasi serta pendampingan usaha. Hasil program IbM ini menunjukkan bahwa peternak kambing-domba antusias sekali dalam mengikuti semua kegiatan baik penyuluhan, pembinaan, demo plot dan pendampingan usaha. Pengadaan bakalan kambing domba sudah diseleksi, manajemen pemeliharaan ternak semi intensif menggunakan kandang beralaskan ayaman kayu bambu, pengadaan hijauan pakan secara liar berupa hijauan lamtoro, sengon dan perdu, peternak sedikit membudidayakan hijauan pakan. Kendala peternak yaitu tidak mempunyai copper pemotong hijauan ramban sehingga pakan banyak tercecer, selain itu tidak ada program penanganan penyakit dengan baik, namun sistem pemasaran hewan qurban dan aqiqohan kambing domba sudah baik. Kesimpulan program IbM ini yaitu beberapa peternak sudah melakukan pengendalian produksi dengan melaksanakan sapta usaha peternakan dengan baik. Disarankan pemanfaatan lahan kosong untuk tanaman leguminosa dan rumput gajah dan dicopping terlebih dahulu, pemberian obat cacing harus terprogram 2-3 kali/ tahun dan pemberian obat kudis seperti WORMECTIN disuntikkan pada ternak yang kudisan.
\end{abstract}

Kata kunci: kambing-domba, bisnis, hewan qurban-aqiqohan.

\section{PENDAHULUAN Kondisi Mitra}

Kelompok bisnis peternakan kambing dan domba ini masih menggunakan sistem semi intensif semua ternaknya dikandangkan terus menerus dan dikawinkan pejantan bukan inseminasi buatan serta 
pemberian pakan dasar masih mengandalkan ketersediaan hijauan lapang seperti rumput, tanaman ramban, leguminosa pohon dan daun semak pahitan yang hidup liar di lahan kosong dan pinggir jalan yang belum dibudidayakan dengan baik. Pakan konsentrat jarang diberikan sehingga pakan yang dikonsumsi belum memenuhi kebutuhan nutrien untuk hidup pokok dan pertumbuhan sehingga produktivitas ternak masih rendah. Kambing dan domba berpotensi sebagai ternak potong cepat berkembangbiak, pertumbuhan dan produksi karkas tinggi bahkan kualitas daging berlemak disukai konsumen serta mampu mentolerir pakan berserat kasar lebih $15 \%$. Apabila manajemen peternakan kambing dan domba secara intensif, maka dapat berpeluang sebagai bisnis yang menghasilkan keuntungan besar. Selain itu harga kambing dan domba dewasa siap potong relatif murah dan terjangkau semua lapisan masyarakat sehingga ternak ini cocok sebagai hewan qurban dan aqiqohan bagi masyarakat muslim ekonomi menengah ke bawah di Malang raya.

Kedua mitra usaha ini telah berkembang menjadi kelompok bisnis peternakan kambing dan domba yang dapat menyediakan hewan qurban dan spesialis untuk aqiqohan. Kelompok peternak hewan qurban diprakarsai oleh bapak Muhammad Nashoha, sedangkan peternak kambing dan domba untuk aqiqohan dimiliki bapak $\mathrm{H}$. Abdul Chamim yang sekarang berkembang menjadi bisnis catering LADIDA. Hasil observasi tim pengabdi terkini pada akhir bulan April tahun 2012 menunjukkan bahwa kondisi peternakan kambing-domba milik kelompok peternak ini cukup membanggakan, kandang yang digunakan sistem panggung permanen terbuat dari kayu dan bambu, atap genteng dan bagian atas dinding tidak rapat sehingga kandang tidak panas dengan kelembaban sekitar $65 \%$. Lantai kandang dari kayu yang berlubang sehingga feses langsung bisa keluar jatuh dan di bawah kandang panggung disediakan penampungan yang setiap 3 bulan sekali feses dikumpulkan dan dibuang ke dalam lubangan yang agak luas disamping kandang yang difungsikan untuk pengomposan alami tanpa atap sehingga terkena panas matahari dan kadang terikut air hujan. Feses ini sebaiknya dibuat kompos menjadi pupuk organik yang bisa dijual atau untuk pemupukan lahan pertanian sendiri. Kandang disekat untuk memisahkan indukan, pejantan, dara dan cempe, hal ini dapat menghindari perkawinan yang tidak diinginkan, keguguran dan resiko kematian kambing da domba akibat perkelaian.

\section{Produksi dan Manajemen Usaha Mitra}

Semua aspek produksi usaha peternakan kambing dan domba yang meliputi pemilihan bibit dan bakalan kambing domba yang unggul, pemberian pakan cukup dan berkualitas, pemeliharaan dan perkandangan, sistem reproduksi, pencegahan penyakit dan pemasaran sudah dikendalikan dengan baik, walau ada beberapa faktor yang belum dikuasai 
dengan benar. Hal ini yang menjadi permasalahan yang dihadapi kelompok bisnis peternakan domba dan kambingdan segera dicari solosinya bersama dengan tim pengabdi program $\mathrm{I}_{\mathrm{b}} \mathrm{M}$ Universitas Islam Malang.

Mitra agrobisnis peternakan kambing dan domba ini memiliki lebih dari sepuluh anggota, setiap peternak mempunyai kandang sendiri di samping atau belakang rumah dengan manajemen usaha yang bervariasi.Ternak domba ada yang dikandangkan dengan lantai tanah yang kering dengan sistem koloni tanpa dipisah-pisahkan antara pejantan, induk, dara dan cempe.Hal ini menimbulkan banyak beresiko yaitu ternak sering berkelai, berebut pakan, perkawinan yang tidak diinginkan dan mengganggu induk bunting. Kambing jantan yang dewasa sudah diikat dalam petak tersendiri dan sewaktu-waktu dikeluarkan untuk keperluan perkawinan atau dimandikan.

Harga penjualan ternak potong ini bervariasi tergantung jenis ternak, jenis kelamin dan umur atau besar kecilnya tubuh ternak, indukan dan dara lebih mahal daripada pejantan. Menurut pemilik mitra usaha, harga jual kambing indukan peranakan etawah yang bagus minimal Rp. 2.500.000, sedang pejantan dewasa yang besar berkisar antara Rp. 2.750.000, sampai Rp. 3.500.000,-. Harga domba lebih murah betina calon indukan Rp. 1.500.000, dan pejantan dewasa minimal Rp. 2.000.000,-. Harga jual kambing dan domba murah terjangkau banyak kalangan masyarakat sehingga permintaan hewan qurban dari tahun ke tahun meningkat, selain itu anakan yang terus bertambah dengan rataan kelahiran pada domba dan kambing sampai 3 kali beranak dalam 2 tahun dengan little size 1-2 per kelahiran.

Pemberian pakan hijauan tidak dipotong-potong dahulu sehingga pakan banyak yang tercecer, selain itu belum mempertimbangkan kualitas dan kandungan gizi dalambahan pakan, serta seharusnya ada kombinasi berbagai jenis hijauan terutama dengan leguminose seperti kaliandra, lamtoro dan daun turi serta limbah tanaman kacang sehingga diharapkan ada efek suplementari nutrien dalam pakan. Peternak sesekali memberikan pakan konsentrat monosubstrat berupa bekatul atau pollard dengan jumlah satu ember untuk 3-4 ekor. Penampilan produksi kambing persilangan terlihat cukup baik, sedang domba lokal kurang baik kelihatan berbulu gimbal dan kotor. Domba lebih menyukai comboran pollard dan bekatul daripada kambing dengan pakan basal berupa hijauan rumput bukan ramban, sedang kambing lebih menyukai hijauan ramban seperti lamtoro, daun gamal, daun nangka dan daunan tanaman pohon lain. Potensi kambing sebagai ternak potong cepat berkembangbiak, pertumbuhan dan produksi karkas tinggi bahkan kualitas daging berlemak disukai konsumen serta mampu mentolerir pakan SK > 15 \% (Ensminger, Oldfield dan Heinemann, 1990). 


\section{Permasalahan Mitra Usaha} berikut:

Permasalahan yang dihadapi mitra usaha diidentifikasi sebagai

- Komposisi dan formulasi pakan yang diberikan tidak tepat.

- Stok hijauan pakan musim kemarau kurang mencukupi kebutuhan.

- Kualitas hijauan pakan yang diberikan rendah

- Belum mempunyai alat pemotong hijauan (copper) sehingga pemberian hijauan utuh dan banyak tercecer dari tempat pakan.

- Produksi hijauan pakan tidak mencukupi kebutuhan kambing dan domba

- Jumlah pemberian pakan asal kenyang saja, kualitas dan efisiensi pakan rendah.

- Produksi ternak kurang optimum dan masih menggunakan pupuk anorganik.

- Pemilihan bakalan dan indukan kambing domba kurang tepat

- Khusus pemilihan hewan qurban harus sehat, tidak cacat dan sudah poel giginya

- Sistem perkawinan alami dan waktu kurang tepat

- Kandang kambing kotor dan timbul bau kurang sedap

- Penyakit skabies sering menyerang kambing dibanding pada domba

- Beberapa kambing dan domba pertumbuhan lambat dan kurus

- Penjualan kambing lebih mahal daripada domba

- Proses culling pada domba dan kambing yang cacat tidak dilakukan

- Belum ada pemisahan khusus untuk kambing bunting dan pejantan pemacek

- Brosur penjualan kambing dan domba kurang tersebar

- Penanganan karkas kambing dan domba pasca penyembelian kurang higinies

- Sistem pemasaran kambing dan domba untuk qurban dan aqiqohan kurang baik

\section{TARGET DAN LUARAN}

\section{Target dan Luaran Kegiatan}

Target program IbM ini adalah tim pengabdi dapat mengembangkan usaha bisnis peternakan hewan qurban dan aqiqohan kambing dan domba yang mendatangkan penghasilan dan keuntungan bagi mitra usaha. Selanjutnya jenis luaran yang dihasilkan dalam kegiatan IbM ini meliputi metode penanaman hijauan pakan menggunakan sistem tiga strata dan tumpangsari sehingga dapat diprediksi produksi hijauan pakan optimal yang dapat mencukupi kebutuhan pakan dan teknologi pengolahan dan 
pengawetan pakan baik fermentasi, ensilase dan hay agar kualitas pakan terkontrol.

Selain itu target luaran program IbM ini yaitu produk pakan konsentrat dari limbah agroindustri lokal seperti onggok limbah tepung tapioka, kulit ari kedelai dari limbah pembuatan tempe, kulit daging kelapa dari industri parut kelapa pengganti bungkil kelapa, bekatul limbah penggilingan padi, pollard, dan ampas tahu ditambah mineral tepung kapur tohor, tepung tulang dan garam dapur. Produk lain yaitu pakan suplemen Urea Molases Blok (UMB) dari campuran urea, molasis, bentonit, makromineral, bahan limbah agroindustri sumber protein dan energi tinggi yaitu kulit daging kelapa, kulit ari kedelai dan onggok terfermentasi yang dibuat bentuk blok. Semua produk pakan diujicobakan kambing domba sehingga diharapkan dapat meningkatkan produktifitas kambing dan domba yang memberi keuntungan dan kesejahteraan bagi peternak mitra.

\section{Prosedur Pembuatan UMB}

- Semua bahan dikeringkan dan digiling untuk memudahkan mixing merata.

- Bahan di timbang sesuai dengan komposisi yang diinginkan.

- Bahan yang berbentuk padat atau kering dicampur, dimulai dari yang jumlahnya paling sedikit, lalu ditambahkan ke bahan yang lebih besar sambil diaduk sampai merata.

- Setelah itu ditambahkan bahan yang cair dan air hangat sedikit demi sedikit sambil diaduk sehingga tidak terjadi gumpalangumpalan dan basah.

- Semua campuran tadi dipanaskan sambil terus diaduk sampai merata panasnya, lamanya pemanasan tergantung pada cara yang dipilih. Untuk cara dingin tidak dipanaskan, cara hangat dipanaskan 3-4 menit dengan suhu tidak lebih $40^{\circ} \mathrm{C}$, sedangkan secara panas dipanaskan 20 menit dengan suhu $100-120^{\circ} \mathrm{C}$.

- Adonan UMB didinginkan dengan meletakkan adonan pada suhu kamar.

- Adonan dicetak dapat menggunakan potongan paralon ditekan dan dikeluarkan, kemudian dikeringkan sinar matahari dan diteduhkan biar tidak terkena hujan.

- Hasil cetakan dikemas dengan plastik bening untuk memudahkan pengontrolan kualitas UMB yang dihasilkan.

\section{METODE PELAKSANAAN}

\section{Metode pendekatan untuk realisasi program $I_{b} M$}

Untuk merealisasikan program $I_{b} M$, maka tim pengabdi menggunakan beberapa metode pendekatan: observasi di lapang, wawancara dengan peternak, penyuluhan yang menarik, demplot pembuatan produk pakan konsentrat dan urea molases blok (UMB) dari bahan pakan lokal, pelatihan 
pengolahan pakan dan pengomposan limbah ternak, uji coba produk pakan untuk pakan, mengenalkan alat copper untuk efisiensi pakan, kemudian melakukan pendampingan kerja pemeliharaan kambing dan domba. Metode penyuluhan mengikuti petunjuk Mardikanto (2009).

\section{Solusi Persoalan Produksi dan Manajemen Usaha}

Tim pengabdi sudah menyusun berbagai kegiatan sebagai langkah solusi atas permasalahan produksi dan manajemen usaha yang sudah teridentifikasi adalah:

- Melakukan observasi ulang ke lokasi mitra dan wawancara sambil berdiskusi untuk memperjelas permasalahan yang dihadapi mitra usaha.

- Memberikan penyuluhan terpadu tentang keseluruhan aspek manajemen pemeliharaan kambing domba, analisa usaha dan perbaikan sistem pemasaran.

- Penyediaan bibit tanaman leguminose dan penaman tumpangsari dengan pola bergilir untuk kesuburan tanah.

- Melakukan reboisasi dengan tanaman pohon sebagai pakan seperti nangka, randu, waru hijau, tanaman turi dll. di sepanjang jalan raya, lahan kosong dan lahan kritis yang berfungsi ganda.

- Memberikan contoh riil cara penanaman leguminosa dan tanaman pangan sistem tiga strata untuk lahan pertanian.

- Demoplot pembuatan pakan konsentrat dan pakan suplemen Urea Molases Block Plus (UMBP).

- Melakukan pelatihan kerja penyusunan (formulasi) ransum, pengawetan dan peningkatan kualitas hijauan pakan dengan melakukan demoplot pembuatan hay, ensilase dan fermentasi hijauan pakan.

- Pengadaan mesin copper untuk pakan hijauan untuk efisiensi pakan

- Model kombinasi pakan basal hijauan ramban leguminose dan non legum rumput untuk suplementary effect dan dicopper dahulu sehingga penyajiannya mudah tidak tercecer.

- Sistem penggemukan kambing dan domba dengan pemberian pakan yang cukup

- Penanganan feses untuk pembuatan pupuk kompos organik.

- Mendampingi dan pembinaan peternak dalam pemeliharaan domba dan kambing menuju peternakan secara intensif professional yang menguntungkan.

- Melakukan culling pada kambing dan domba pejantan yang cacat dan fisiknya tidak normal menghindari perkawinan yang tidak dikehendaki sekaligus peningkatan pertumbuhan kambing domba optimal dan daging yang berkualitas. 
- Membuat rekording dan program sistem perkawinan kambing dan domba untuk ketepatan waktu kapan ternak dikawinkan dan beranak sehingga mempunyai calving interval 3 kali dalam 2 tahun dan servis conception yang rendah.

- Melakukan analisa usaha dan keuntungan bisnis peternakan kambing dan domba yang telah diusahakan.

- Melakukan diskusi lingkup promosi brosur dan pemasaran bisnis kambing qurban dan aqiqohan yang menguntungkan.

\section{HASIL DAN PEMBAHASAN}

\section{Sosialisasi dan Persiapan Program IbM}

Pada tahap awal ketua tim pengabdi melakukan ijin lokasi dan sosialisasi program lbM dengan mitra usaha seperti pada Gambar 1. Kemudian melakukan persiapan kegiatan, inventarisasi kebutuhan materi, reobservasi lapang. Pengadaan materi utama meliputi bahan pakan (bekatul, pollard, bungkil kedelai, empok jagung serta limbah agroindustri lokal meliputi kulit daging kelapa, kulit biji kedelai dan onggok terfermentasi, urea, mineral dan molasses) untuk pakan konsentrat dan permen UMB untuk kambing dibeli dari Koperasi Unit Desa DAU Malang, tanaman pangan pohon nangka dan leguminosa untuk reboisasi sebagai hijauan pakan dbeli dari pembibitan tanaman CV. Megah Abadi, Mulyoagung, Malang seperti pada Gambar 2.
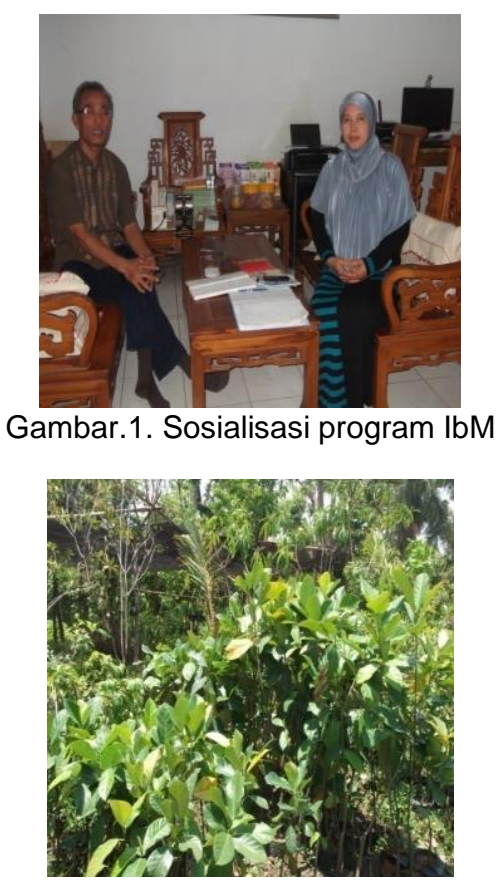

Gambar.2. Kebun bibit tanaman nangka 
Setelah berdiskusi dengan mitra usaha, maka tim pengabdi dapat menentukan beberapa prioritas permasalahan harus ditangani yaitu:

- Pemilihan kambing dan domba jantan sebagai bakalan yang unggul.

- Pengadaan dan strategi pemberian pakan yang cukup gizi bagi kambing domba.

- Pengawetan dan peningkatan kualitas hijauan pakan.

- Formulasi dan pembuatan pakan konsentrat, Urea molases block (UMB).

- Manajemen pemberian pakan yang tepat (model kombinasi hijauan leguminose dengan ramban non legum atau rumput) untuk meningkatkan efisiensi pakan

- Manajemen kandang yang nyaman dan terhindar perkelaian antar ternak

- Pencegahan penyakit cacing dan skabies melalui oral atau suntikan

- Sistem perkawinan dan program pembibitan untuk mendapatkan bibit unggul

- Perbaikan sistem penjualan kambing dan domba

- Penanganan limbah ternak baik feses, urine dan sisa pakan

- Model penanaman hijauan pakan sistem tiga strata dalam lahan pertanian dengan tanaman gliriside, lamtoro dan pohon nangka sebagai pagar, di bagian dalamnya ditanami ubi jalar, dan sayuran dan bagian paling dalam tanaman pangan jagung, padi atau tanaman kacang

- Melakukan reboisasi tanaman pohon multiguna sekaligus sebagai pakan ternak.

- Sistem pemotongan ternak dan penanganan karkas kambing yang tepat

- Memperbaiki sistem pemasaran kambing - domba untuk qurban dan aqiqohan Skematis kegiatan dalam intensifikasi peternakan kambing domba sebagai hewan qurban atau aqiqohan disajikan dalam Gambar 3. 


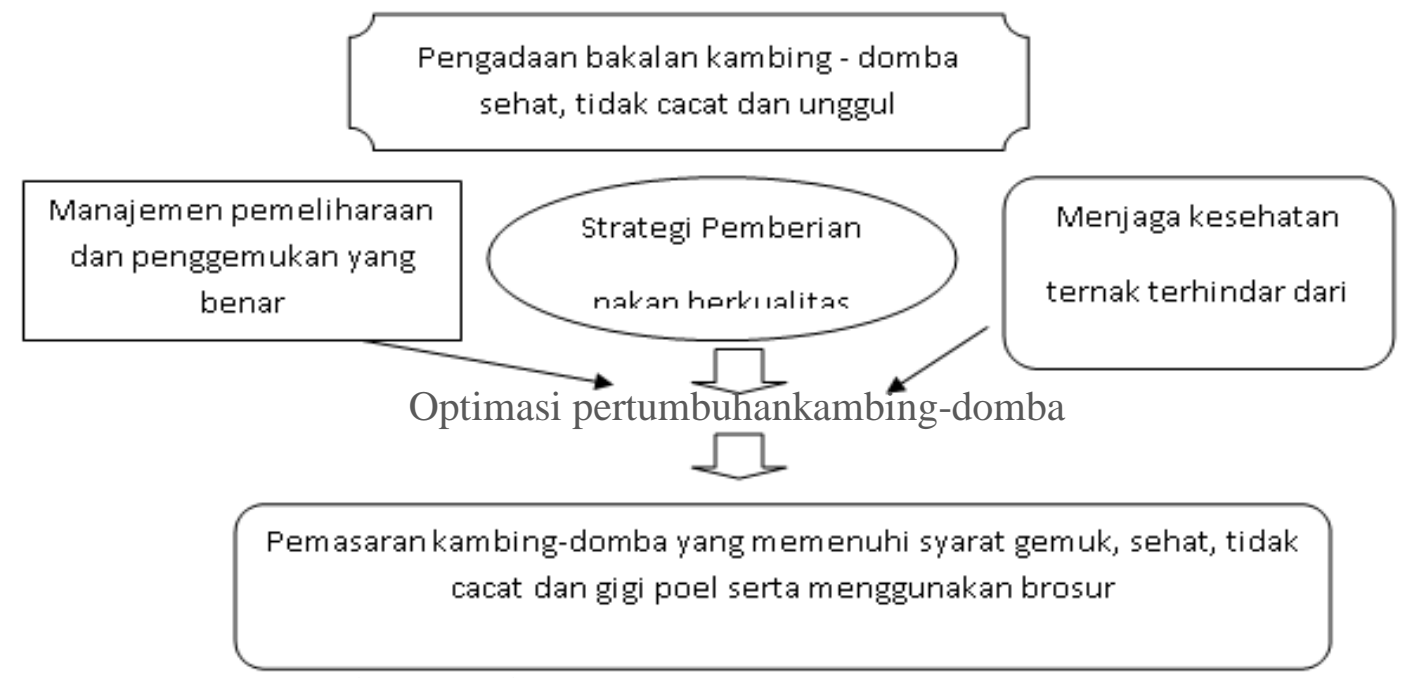

\section{Penyuluhan}

Gambar 3. Skema peternakan intensif kambing dan domba

Kegiatan penyuluhan dan persiapan demoplot dilakukan melalui konfirmasi dan koordinasi dengan peternak kambing-domba di Karangbesuki, Sukun, Kota Malang. Alat bantu untuk penyuluhan yaitu LCD, Laptop, dan kamera. Kegiatan ini dihadiri anggota dan ketua dan masyarakat peternak desa setempat.Pemusatan kegiatan penyuluhan dilakukan di rumah peternak. Waktu pelaksanaan kegiatan penyuluhan dilakukan pada sore hari setelah sholat dhuhur sekitar pukul 14.00 sampai 1600 WIB, hal ini dilakukan dengan maksud tidak mengganggu kesibukan dan tugas pokok masyarakat tani peternak setempat sehingga mudah dikondisikan dengan baik.

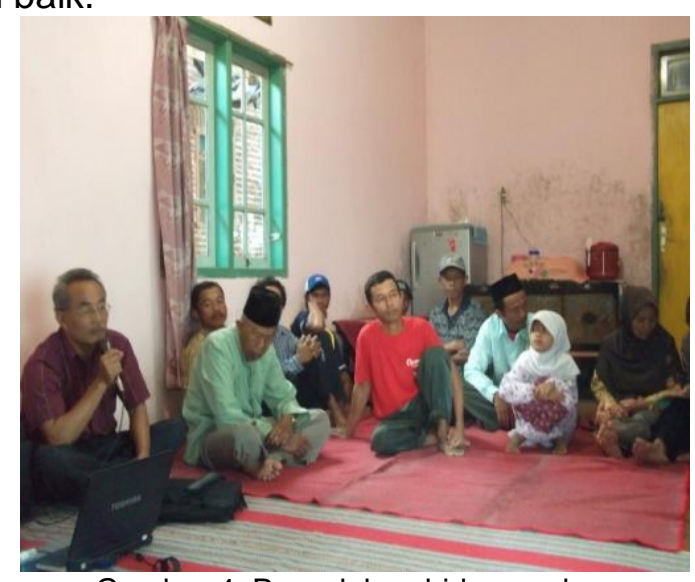

Gambar 4. Penyuluhan bidang pakan

Penyampaian materi penyuluhan ini disertai diskusi guna mengevaluasi minat peternak terhadap materi penyuluhan dan tukar pengalaman teoritis pengendalian produktivitas ternaki antara tim pengabdi 
dengan mitra usaha. Penyuluhan dilakukan secara massal dan dilanjutkan secara individu pada saat kunjungan lapang untuk memberikan bimbingan dan konsultasi secara personal. Tujuan kegiatan ini adalah untuk meningkatkan pengetahuan dan memberikan motivasi pada para peternak untuk melakukan usaha bisnis kambing-domba sebagai hewan qurban dan aqiqohan secara intensif. Adapun materi penyuluhan yang disampaikan ditekankan pada pemahaman sapta usaha peternakan yang meliputi pemilihan dan penggunaan bibit ternak yang unggul, pemberian pakan yang bergizi dan jumlah yang cukup, sistem perkandangan dan manajemen pemeliharaan yang benar, sistem perkawinan dan perkembangbiakan yang baik, sistem pencegahan dan pengobatan penyakit dengan benar, penanganan produk dan sistem pemasaran/penjualan yang menguntungkan.

\section{Demoplot Fermentasi Pakan dan Pembuatan Pakan Suplemen UMBP}

Fermentasi limbah agroindustri lokal dari kombinasi kulit daging kelapa (KDK), kulit biji kedelai (KBK) dan onggok yang disebut KKO dalam kondisi kering udara yang dikombinasikan 60\% : 20\% dan 20\% dengan menggunakan kultur bakteri selulolitik Cellulomonas sebanyak $10^{8} \mathrm{cfu} / \mathrm{g}$ BK bahan dengan kelembaban atau kadar air 60\%, diaduk merata, dimasukkan dalam polybag dan lama inkubasi 8 hari secara anaerob pada suhu ruang sekitar $25-27^{\circ} \mathrm{C}$. Kemudian dilakukan pengambilan sampel bahan untuk dianalisis kandungan nutrien baik sebelum dan sesudah perlakuan fermentasi. Metode fermentasi limbah agroindustri sebagai campuran pakan, konsentrat atau suplemen urea molasis blok disajikan pada Gambar 5.

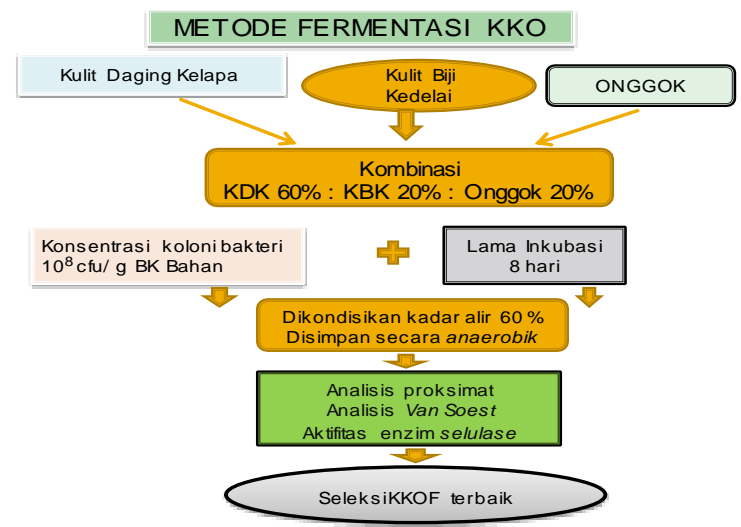

Gambar 5. Diagram alir metode fermentasi pakan

Setelah fermentasi KKO dipanen, kemudian dilakukan pengeringan matahari selama 2-3 hari sampai kandungan kadar air kurang dari $12 \%$ maka produk KKOF ini siap disajikan pada kambing atau disimpan untuk memenuhi kebutuhan pakan kambing sehari-harinya sebagai campuran 
pakan. Bahan pakan yang kering (BK > $86 \%$ ) akan awet mempunyai daya simpan lama dan tidak ditumbuhi jamur. Kandungan gizi dalam BK produk fermentasi KKOF adalah $\mathrm{BK}=87,5 \%, \mathrm{BO}=92,637 \%, \mathrm{PK}=11,55 \%$, $\mathrm{LK}=31,29 \%, \mathrm{SK}=17,34 \%$, NDF $=28,23 \%, \mathrm{ADF}=18,33 \%$, selulosa $=8,89$ $\%$ dan lignin $=7,13 \%$. Hambatan dalam pengadaan pakan fermentasi ini adalah pengeringan dengan matahari apabila turun hujan merepotkan harus cepat ditutup pakai terpal, bilamana tidak bahan pakan akan rusak.

Pembuatan suplemen UMB dilakukan dengan membuat adonan dari campuran urea $3 \%$, molasses $32 \%$, pollard $15 \%$, DDGS $10 \%$, KKOF $35 \%$, mineral mix $3 \%$, garam dapur $2 \%$ ditambah semen sebanyak $12 \%$, diaduk homogen, ditambah air sambil diaduk merata sampai basah. Penggunaan urea dalam pakan ruminansia dibatasi 2-3 \% dan perlu dicampur dengan karbohidrat mudah tercerna untuk mempercepat sintesa protein mikroba (Soebarinoto, Chuzaemi dan Mashudi, 199I). Adonan UMB basah dicetak dalam paralon ukuran $3 \mathrm{dim}$, bagian tengah lubang dipadatkan dengan tekanan dan adonan dikeluarkan dengan mengangkat paralon dan penekanan sedikit demi sedikit, kemudian dikeringkan dengan cara diangin-anginkan pada ruangan yang beratap (Gambar 7 dan 8). Produk UMBP ini merupakan pakan suplemen kaya gizi dan palatable, pemberian suplemen UMB dengan cara digantungkan dan dikonsumsi kambing dengan cara menjilat-jilat. Menurut Siregar (1990) standar nutrien konsentrat untuk penggemukan kambing PK minimal 16\% dan serat kasar kurang $18 \%$.

\section{Pelaksanaan Reboisasi}

Reboisasi tanaman pohon pangan (nangka, mangga, pepaya, pisang) dilakukan di sekitar kandang, sedangkan tanaman pakan di sepanjang jalan, lahan kosong dan lahan kritis. Reboisasi ini diharapkan menghasilkan buah fungsional mendatangkan tambahan penghasilan dan hijauan pakan kambing dan domba.

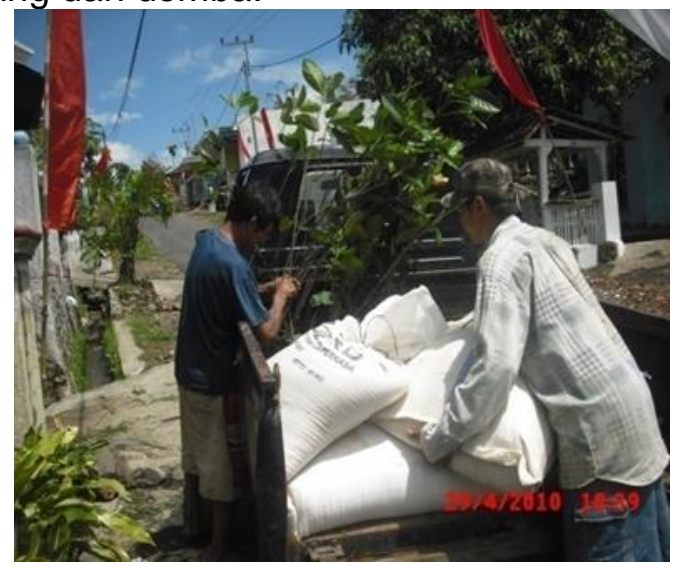

Gambar 6. Pengiriman pakan dan bibit 
Model penanaman hijauan dengan Sistem Tiga Strata di lahan pertanian diatur: bagian luar ditanami tanaman pagar seperti glirisidia, lamtoro dan pohon nangka di tanam pada ujung pojok, bagian dalam ditanami umbiumbian, sedang bagian dalam tanaman pokok kombinasi jagung, padi dan kacang menjaga kesuburan tanah.Bagian luar/pagar (tanaman gamal, lamtaro, kaliandra dan pohon nagka)

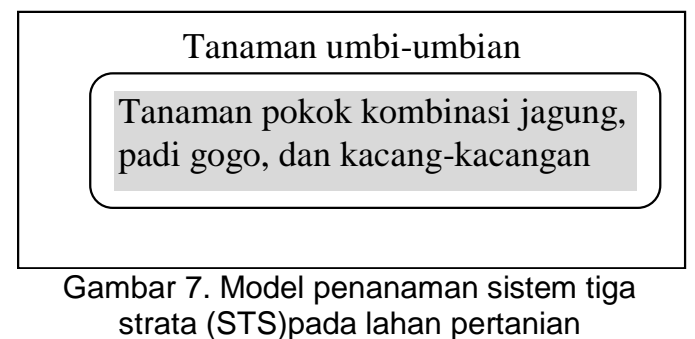

Model reboisasi tanaman fungsional yang produktip direalisasikan dengan cara menanam tumbuhan pangan seperti pohon nangka dan pepaya atau hijauan pakan meliputi kaliandra, turi, lamtoro atau tanaman pohon di sepanjang jalan dan lahan kritisuntuk menjaga kelestraian lingkungan dan penyediaan pakan yang berkualitas.

\section{Penjualan Hewan Qurban dan Aqiqohan}

Hewan qurban di Malang kebanyakan adalah kambing dan sapi, sedang domba digunakan sebagai hewan aqiqohan yang biasanya dipotong pada umur lebih muda minimal setengah tahun. Persyaratan syar'i hewan qurban adalah hewan potong berkaki empat seperti sapi, kerbau, onta, kuda, kambing dan domba yang sehat, tidak cacat dan poel (gigi susu sudah ganti gigi tetap yang ukurannya lebih besar). Syarat gigi poel ini kuat sekali sehingga jangan sampai niat qurban tetapi hewan qurbannya tidak poel maka pahalanya shodaqoh Perintah penyembelihan hewan kurban diwajibkan bagi muslim yang sesuai dengan kemampuan finansialnya. Di Malang raya harga kambing qurban tahun 2013 dijual Rp. 1750.000 - Rp. $3500.000,-$. Penjualan kambing qurban dilakukan pajangan di perumahan menjelang hari Idul Adha seperti pada Gambar 8.

Kewajiban menunaikan aqiqoh bagi ummat muslim sekali seumur hidup untuk anak muslim 2 ekor dan muslimah 1 ekor kambing atau domba. Harga kambing domba aqiqohan berkisar Rp. 960.000, - Rp. 1.850 .000 , tergantung jumlah tusuk sate antara 200 sampai 750 tusuk dan gule dilengkapi dengan paket nasi kotak seharga Rp. 8500,/kotak sampai Rp. 12.000,/ kotak tergantung paketan A, B dan C (Nasi putih, mie goreng, kerupuk udang dan telur asin. Bisnis hewan aqiqohan ini sudah berkembang menjadi usaha catering berganti nama ZANIA menjadi LADIDA, membuka cabang di tiga Kota Probolinggo, Blitar dan Kediri dan dikendalikan di Malang. Sistem pemasaran hewan aqiqohan menggunakan 
burner dipasang depan rumah dan brosur yang diedarkan di tempat strategis seperti pada Gambar 9.

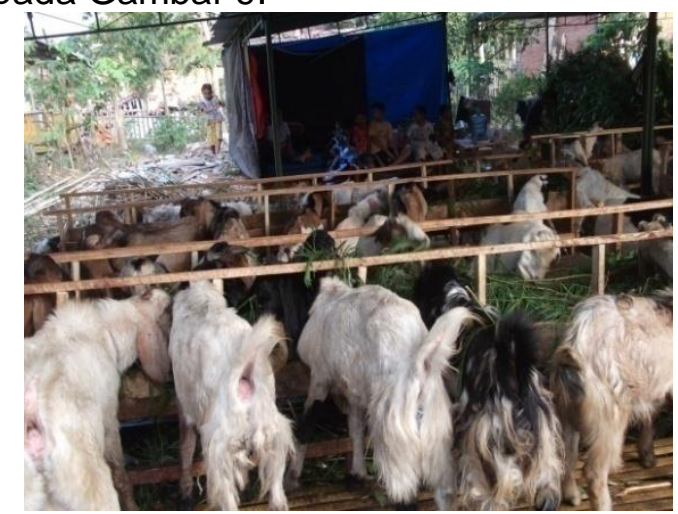

Gambar.8. Penjualan kambing qurban

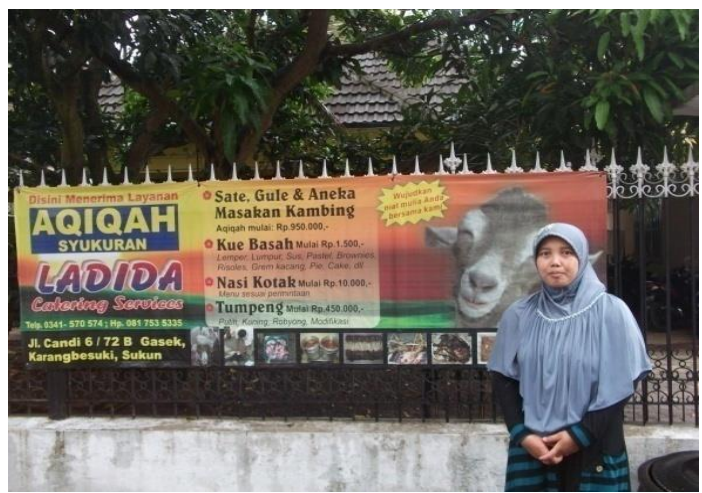

Gambar 9. Penjualan kambing aqiqohan

\section{KESIMPULAN DAN SARAN}

\section{Kesimpulan}

Program IbM ini mendapatkan respon yang baik dari mitra usaha bisnis kambing - domba qurban dan aqiqohan, bisnis ini telah diusahakan selama 10 sampai 15 tahun. Pengadaan ternak kurang tepatlangsung dibeli dadaan dari peternak atau pasar hewan dan tidak dilakukan penggemukan di kandang sendiri. Sedangkan hewan qurban dititipkan peternak selama 1 - 2 bulan yang dilakukan penggemukan yang diberi pakan konsentrat terutama pollard untuk comboran. Pembuatan pakan suplemen UMBP dari adonan urea, molases, mineral, dan bahan pengisi (pollard, DDGS, bekatul dan KKOF) serta bahan pengikat semen.UMBP bermanfaat untuk meningkatkan PBB kambingdan memberikan tambahan keuntungan bagi peternak. 


\section{Saran}

Disarankan mitra usaha bisnis kambing-domba hewan qurban dan aqiqohan senantiasa mengendalikan produksi dengan mengacu pada sapta usaha peternakan sehingga bisnisnya menguntungkan.

\section{UCAPAN TERIMA KASIH}

Tim pengabdi mengucapkan terima kasih kepada DP2M Ditjen Dikti Depdikbud Republik Indonesia di Jakarta, atas pemberian dana program pengabdian masyarakat tahun anggaran 2013 sehingga program IbM ini telah dapat kami laksanakan dengan sebaik-baiknya. Juga kepada mitra pelaku bisnis kambing domba sebagai hewan qurban dan aqiqohan di Karangbesuki, Sukun, Kota Malang yang telah bekerjasama dengan tim pengabdi Unisma dengan baik.

\section{DAFTAR PUSTAKA}

Ensminger, M.E., J.E. Oldfield, and W.W. Heinemann. 1995. Feed and Nutrition. The Ensminger Publishing Company, California.

Mardikanto, T. 2009. Sistem Penyuluhan Pertanian. Pusat Pengembangan Agribisnis dan Perhutanan Sosial. Sebelas Maret University Press. Surakarta.

Siregar, 1990. Makanan Ternak Ruminansia. Penebar Swadaya. Jakarta.

Soebarinoto, S. Chuzaemi dan Mashudi. 199I. Ilmu Gizi Ruminansia. Universitas Brawijaya. Animal Husbandry Project Malang.

Tim Penyusun. 2013. Panduan Pelaksanaan Penelitian dan Pengabdian KepadaMasyarakat di Perguruan Tinggi. Edisi IX. Direktorat Penelitian dan Pengabdian Kepada Masyarakat, Direktorat Jendral Perguruan Tinggi, Kementrian Pendidikan dan Kebudayaan 